\title{
Phosphorus on performance, hematological, biochemical, and bone parameters of growing pigs
}

\author{
Influência de fósforo disponível sobre parâmetros de desempenho, hematológicos, \\ bioquímicos e ósseos de suínos em crescimento
}

\author{
Jana Euclydes Drews ${ }^{\mathrm{I}}$ Douglas Haese ${ }^{\mathrm{I}^{*}}$ João Luís Kill ${ }^{\mathrm{I}}$ Lucas Lemke Lorenzoni $^{\mathrm{I}}$ \\ Rafael Bozini Pimentel ${ }^{I}$ Juliano Pelição Molino ${ }^{\text {III }}$ \\ Alysson Saraiva' Carolina D'Ávila Possatti ${ }^{I}$
}

\section{ABSTRACT}

The purpose of this study was to assess the levels of available phosphorus (AP) in the diet of growing pigs selected for lean deposition on the hematological, biochemical, and bone performance parameters. A total of 64 commercial hybrid pigs $(32$ castrated males and 32 females; mean initial weight: $23.31 \pm 2.4 \mathrm{~kg}$; age: 55-90 days) were used. Animals were distributed into a randomized block design with four treatments, eight replicates, and two animals (one male and one female) per experimental unit. The treatments consisted of a basal diet and another three diets, which were obtained by supplementing the basal diet with dicalcium phosphate replacing the inert phosphate, resulting in four diets with $0.100,0.180,0.260$, and $0.340 \%$ of available phosphorus. The levels of available phosphorus quadratically influenced the daily weight gain, feed consumption, and feed conversion, which increased up to the estimated levels $0.331 ; 0.330$, and $0.302 \%$ of available phosphorus. Levels of phosphorus showed no influence on the hematological parameters, which remained within the reference values. Levels of available phosphorus increased linearly the ash and phosphorus contents in the metacarpal bone and decreased linearly the alkaline phosphatase activity. Levels of available phosphorus (0.331 and $0.302 \%$, corresponding to a daily intake of 5.73 and $5.18 \mathrm{~g} \mathrm{~d}^{-1}$ ) provided respectively the best results for weight gain and feed conversion in pigs with high genetic potential, without change in hematological parameters.

Key words: requirement, blood tests, mineral, genetic potential.

\section{RESUMO}

O objetivo deste estudo foi avaliar niveis de fósforo disponivel em rações para suínos em crescimento, selecionados para deposição de carne, sobre os parâmetros de desempenho, hematológico, bioquimico e ósseo. Foram usados 64 suínos híbridos comerciais (32 machos castrados e 32 fêmeas; peso médio inicial:
23,31 22,4 kg; idade: 55-90 dias). Os animais foram distribuidos em blocos casualizados com quatro tratamentos, oito repetições e dois animais (um macho e uma fêmea) por unidade experimental. Os tratamentos consistiram em uma ração basal e em outras três rações, obtidas pela suplementação da ração basal com fosfato bicálcico em substituição ao inerte, resultando em quatro rações com 0,100, 0,180, 0,260, 0,340\% de fósforo disponivel. Os niveis de fósforo disponivel influenciaram de forma quadrática o ganho de peso diário, o consumo de ração e a conversão alimentar, que aumentaram até o nivel estimado de 0,331, 0,330 e 0,302\% de fösforo disponivel, respectivamente. Não houve influência dos niveis de fósforo sobre os parâmetros hematológicos que permaneceram dentro dos valores de referência. Os niveis de fósforo disponivel influenciaram de forma linear crescente os teores de cinzas efósforo no metacarpo dos animais e, de forma decrescente, a atividade da fosfatase alcalina. Os niveis de fósforo disponível, de 0,331 e 0,302\%, correspondentes ao consumo diário de 5,73 e 5,18g $d^{-1}$, proporcionaram, respectivamente, os melhores resultados de ganho de peso e conversão alimentar em suinos de alto potencial genético, sem alterações nos parâmetros hematológicos.

Palavras-chave: exigência, hemograma, mineral, potencial genético.

\section{INTRODUCTION}

Phosphorus is an essential mineral for the formation and maintenance of bone structure, playing additionally a number of functions in the body. According to UNDERWOOD \& SUTTLE (1999), phosphorus is found in a high concentration in bone tissue where together with calcium they form

\footnotetext{
'Programa de Pós-graduação em Ciência Animal, Universidade Vila Velha (UVV), 29102-606, Vila Velha, ES, Brasil. E-mail: douglas.haese@uvv.br. "Corresponding author.

IIUniversidade Federal de Viçosa (UFV), Viçosa, MG, Brasil.

IIIFaculdade de Santa Teresa (ESFA), Santa Teresa, ES, Brasil. 
hydroxyapatite, which is the major constituent of the skeleton. Phosphorus portion not related to the structural function in the body is contained in highvalue organic molecules, such as DNA, RNA, ATP, phospholipids, and phosphorylated proteins.

According to CORREA et al. (2006), genetically improved pigs have as their main characteristics high performance and carcass yield, mainly provided by a high rate of protein deposition. HITTMEIER etal.(2006) reported that when phosphorus consumption is low, low genetic potential animals prioritize phosphorus deposition in their bones to the detriment of muscle deposition whereas animals with high genetic potential prioritize phosphorus deposition in their muscles for general development. Thus, knowledge of nutritional needs of this mineral helps nutritionists formulate diets for optimal performance with minimal excretion in the environment.

Effects of genetic breeding and other factors such as ambient temperature, physiological state, and age on phosphorus requirement for growing pigs are well understood among nutritionists. However, few studies in the literature correlate phosphorus need for optimal growth and their effects on the hematological and biochemical parameters in pigs.

Therefore, the purpose of this study was to assess the levels of available phosphorus (AP) in diets for pigs with high genetic potential aged 55-90 days on the hematological, biochemical, and bone performance parameters.

\section{MATERIALS AND METHODS}

A total of 64 hybrid pigs (32 castrated males and 32 females, genetic lineage Agroceres PIC $^{\circledR}$; mean initial weight: $23.31 \pm 2.4 \mathrm{~kg}$; age: $55-90$ days) were used. Pigs were housed in individual pens $\left(1.90 \times 2.90 \mathrm{~m}, 5.51 \mathrm{~m}^{2}\right.$, concrete floor; asbestos roof; roof height: $2.50 \mathrm{~m}$ ) provided with precast concrete troughs and pacifier-type drinkers.

The animals were distributed into a randomized block design with four treatments, eight replicates, and two animals (one male and one female) per experimental unit. The experimental diets (Table 1) included corn, soy bean meal, and were supplemented with industrial amino acids to meet the nutritional requirements of growing pigs (ROSTAGNO et al., 2011), except available phosphorus. Treatments consisted of a basal diet and another three diets, which were obtained by supplementing the basal diet with dicalcium phosphate replacing inert phosphate, resulting in four diets with $0.100,0.180,0.260$, and $0.340 \%$ of available phosphorus.
Animals were fed ad libitum with water and with experimental diets. Diets, remained and waste were weighed weekly to determine the feed intake during the experimental period. The animals were weighed at the beginning and end ( 35 days) of the study to determine the daily weight gain and feed conversion.

On the last day of the experiment, blood samples (six animals per treatment) were collected for analysis of the hematological and biochemical parameters. Samples were collected by puncturing (syringe: $5.0 \mathrm{~mL}$, needle $25 \times 8 \mathrm{~mm}$ ) of the cephalic vein and stored in sterile tubes. The samples were stored in tubes without anticoagulant for biochemical analysis or with anticoagulant (sodium ethylenediaminetetraacetate, EDTA, $1 \mathrm{mg} \mathrm{ml}^{-1}$ blood) for hematological analysis.

Samples stored in tubes without anticoagulant for biochemical analysis were centrifuged (1000rpm, 15min) to obtain blood serum. The determinations of calcium $(\mathrm{Ca})$, phosphorus $(\mathrm{P})$, alkaline phosphatase (AP) concentrations in serum were performed using a semiautomatic biochemical analyzer (BIO 200 F; Bioplus; Vila Velha, ES, Brazil).

In order to obtain the hematological variables of erythrocytes (red blood cell count) and hemoglobin, an automatic electronic analyzer (model SDH 3 VET, Labtest, Vila Velha, ES, Brazil) was used. Leukocytes were counted using a hand counter, and white blood cells (neutrophils, basophils, leukocytes, and lymphocytes) were counted differentially and evaluated by means of blood smear in light microscope (magnification: 1000x) (WEISS \& WARDROP, 2010).

At the end of the experimental period, five animals per treatment were slaughtered (close to the average weight; after 12-h fasting) for collection of the right paw. Animals were humanly slaughtered with high-voltage $(450 \mathrm{~V})$ and low-amperage $(0.5 \mathrm{~A})$ electric shock desensitization behind their ears (temporal fossae). They were then bled (within 30s) by section of the large vessels or direct puncture of the heart.

After the paws were collected, they were boiled in water (aluminum pan; 25min) to soften the skin and flesh surrounding bones and remove the third metacarpal bone. The metacarpal bone of each animal was kept in a ventilated oven $\left(65^{\circ} \mathrm{C}, 72 \mathrm{~h}\right)$ and subjected to breakage. After the bones were broken, they were defatted (Soxhlet extractor) dried in a ventilated oven $\left(105^{\circ} \mathrm{C} ; 24 \mathrm{~h}\right)$, and triturated in a ball mill. Bone ash contents (BA) and phosphorus (P) in the bones were determined according literature of SILVA \& QUEIROZ (2002). 
Table 1 - Levels of available phosphorus in feeds for pigs (aged 55-90 days) with high genetic potential.

\begin{tabular}{|c|c|c|c|c|}
\hline \multirow{2}{*}{ Ingredients $(\%)$} & \multicolumn{4}{|c|}{--Available phosphorus levels, \%-- } \\
\hline & 0.100 & 0.180 & 0.260 & 0.340 \\
\hline Corn bran & 73.700 & 73.700 & 73.700 & 73.700 \\
\hline Soy bean meal (46\%) & 22.600 & 22.600 & 22.600 & 22.600 \\
\hline Soybean oil & 0.400 & 0.400 & 0.400 & 0.400 \\
\hline Limestone, calcitic & 1.600 & 1.325 & 1.050 & 0.770 \\
\hline Phosphate, dicalcium & 0.000 & 0.425 & 0.875 & 1.325 \\
\hline Sodium chloride (common salt) & 0.400 & 0.400 & 0.400 & 0.400 \\
\hline L-Lysine $\mathrm{HCl}(78 \%)$ & 0.285 & 0.285 & 0.285 & 0.285 \\
\hline DL-Methionine (98\%) & 0.060 & 0.060 & 0.060 & 0.060 \\
\hline L-Threonine (98\%) & 0.070 & 0.070 & 0.070 & 0.070 \\
\hline Choline chloride $(60 \%)$ & 0.050 & 0.050 & 0.050 & 0.050 \\
\hline Premix, Vitamin ${ }^{1}$ & 0.100 & 0.100 & 0.100 & 0.100 \\
\hline Premix, Mineral $^{2}$ & 0.100 & 0.100 & 0.100 & 0.100 \\
\hline Colistin sulphate $(50 \%)$ & 0.008 & 0.008 & 0.008 & 0.008 \\
\hline Enramycin $(8 \%)$ & 0.006 & 0.006 & 0.006 & 0.006 \\
\hline Inert (kaolin) & 0.621 & 0.471 & 0.296 & 0.126 \\
\hline \multicolumn{5}{|c|}{---Calculated nutritional composition-- } \\
\hline Protein, crude, $\%$ & 16.660 & 16.660 & 16.660 & 16.660 \\
\hline Lysine, digestible, $\%$ & 0.940 & 0.940 & 0.940 & 0.940 \\
\hline Methionine + Cystine, digestible, $\%$ & 0.560 & 0.560 & 0.560 & 0.560 \\
\hline Threonine, digestible, $\%$ & 0.610 & 0.610 & 0.610 & 0.610 \\
\hline Tryptophan, digestible, $\%$ & 0.170 & 0.170 & 0.170 & 0.170 \\
\hline Arginine, digestible, $\%$ & 1.000 & 1.000 & 1.000 & 1.000 \\
\hline Sodium, $\%$ & 0.180 & 0.180 & 0.180 & 0.180 \\
\hline Calcium, $\%$ & 0.700 & 0.700 & 0.700 & 0.700 \\
\hline Calcium, analyzed, \% & 0.683 & 0.686 & 0.688 & 0.689 \\
\hline Phosphorus, total, \% & 0.310 & 0.380 & 0.460 & 0.540 \\
\hline Phosphorus, analyzed, \% & 0.302 & 0.372 & 0.450 & 0.531 \\
\hline Phosphorus, available, $\%$ & 0.100 & 0.180 & 0.260 & 0.340 \\
\hline
\end{tabular}

${ }^{1}$ Content kg-1 : Niacin: 13,000mg; vitamin A: 2.666.000UI; vitamin $\mathrm{B}_{2}: 1,600 \mathrm{mg}$; biotin: $16.56 \mathrm{mg}$; choline: 120,000mg; folic acid: $266 \mathrm{mg}$; vitamin $\mathrm{B}_{12}: 11,000 \mu \mathrm{g}$; vitamin $\mathrm{K}: 2,666 \mathrm{mg}$; pantothenic acid: 7,000mg; vitamin E: $10,000 \mathrm{mg}$; vitamin $\mathrm{D}_{3}: 1,000,000 \mathrm{UI}$; vitamin $\mathrm{B}_{6}: 666 \mathrm{mg}$; antioxidant: $2,160 \mathrm{mg}$; Excipient: q.s. to $1,000 \mathrm{~g}$.

${ }^{2}$ Content/Kg: Selenium: 130mg; Manganese: 40,020mg; Copper: 15,000mg; Iron: 24,930mg; Cobalt: 168mg; Iodine: 1,417mg; Zinc: 74,971mg: Excipient: q.s. to $1,000 \mathrm{~g}$.

Statistical analysis was performed using the procedures for variance and regression analysis in the System for Statistical and Genetic Analysis (SAEG, for Sistema para Análises Estatísticas e Genéticas, v. 8.0, UFV, 2000; Viçosa, MG, Brazil). Performance characteristics, bone parameters, and biochemical and hematological analyses were interpreted using variance analysis ( $5 \%$ probability). The levels of available phosphorus were estimated using linear or quadratic regression, according to data best fit for each variable.

\section{RESULTS AND DISCUSSION}

A quadratic effect $(\mathrm{P}<0.01)$ of available phosphorus levels on the daily weight gain (DWG) of animals was observed (Table 2), increasing the level of available phosphorus up to $0.331 \%$. This corresponds to the consumption of $5.73 \mathrm{~g} \mathrm{~d}^{-1}$ of available phosphorus, according to the equation $\hat{Y}=-5.8644 x^{2}+3.8794 x+0.16891 \quad\left(R^{2}=0.98\right)$. This result is different from that obtained by SARAIVA et al. (2011), who assessed the requirement of available phosphorus in female commercial pigs (Agroceres-Pic; 30-60kg) and reported a requirement of $0.372 \%$. AROUCA et al. (2009) used commercial hybrid castrated male pigs (AgroceresPic) genetically selected for a high percentage of lean meat reported a requirement of $0.420 \%$ for aP. EKPE et al. (2002) used commercial hybrid male and female pigs $(23-60 \mathrm{~kg})$ with high genetic 
Table 2 - Influence of available phosphorus levels in feed for pigs (aged 55-90 days) on performance parameters.

\begin{tabular}{|c|c|c|c|c|c|c|c|c|c|c|}
\hline \multirow{3}{*}{$\begin{array}{l}\text { Variables } \\
\text { Initial mean weight, } \mathrm{kg}\end{array}$} & \multicolumn{8}{|c|}{---1 } & \multirow{3}{*}{$\frac{P \text { values }}{\mathrm{NS}}$} & \multirow{3}{*}{$\begin{array}{l}\mathrm{VC}, \% \\
5.90\end{array}$} \\
\hline & \multicolumn{2}{|c|}{------0.100------ } & \multicolumn{2}{|c|}{-------0.180-------- } & \multicolumn{2}{|c|}{--------0.260------- } & \multicolumn{2}{|c|}{----------0.340--------- } & & \\
\hline & 23.29 & \pm 2.36 & 23.22 & \pm 2.44 & 23.21 & \pm 2.52 & 23.11 & \pm 2.77 & & \\
\hline Daily weight gain ${ }^{1}, \mathrm{~kg} \mathrm{~d}^{-1}$ & 0.505 & \pm 0.03 & 0.657 & \pm 0.06 & 0.801 & \pm 0.05 & 0.803 & \pm 0.07 & 0.001 & 8.35 \\
\hline Feed conversion ${ }^{1}$ & 2.63 & \pm 0.16 & 2.33 & \pm 0.09 & 2.16 & \pm 0.08 & 2.16 & \pm 0.15 & 0.002 & 5.40 \\
\hline Daily feed intake ${ }^{1}, \mathrm{~kg} \mathrm{~d}^{-1}$ & 1.33 & \pm 0.11 & 1.53 & \pm 0.14 & 1.73 & \pm 0.11 & 1.72 & \pm 0.07 & 0.019 & 7.21 \\
\hline Phosphorus daily consumption ${ }^{2,}, \mathrm{~g} \mathrm{~d}^{-1}$ & 1.32 & \pm 0.12 & 2.75 & \pm 0.25 & 4.49 & \pm 0.30 & 5.86 & \pm 0.24 & 0.001 & 6.58 \\
\hline
\end{tabular}

${ }^{1}$ Quadratic effect; ${ }^{2}$ Linear effect; NS - Non significant; VC - Variation coefficient.

potential for meat deposition and estimated a level of $0.330 \%$ for better DWG.

Feed conversion was influenced in a quadratic form $(\mathrm{P}<0.01)$ by the treatments (Table 2$)$. It improved the estimated level of $0.302 \%$ available phosphorus, corresponding to the estimated consumption of $5.18 \mathrm{~g} \mathrm{~d}^{-1}$ available phosphorus, according to the equation $\hat{Y}=11.966 x^{2}-7.251 x+3.237$ $\left(\mathrm{R}^{2}=0.98\right)$. For a better feed conversion, SARAIVA et al. (2009) and AROUCA et al. (2009) recommended a daily intake of 7.36 e $9.11 \mathrm{~g}$ of phosphorus available, respectively.

The experiments by AROUCA et al. (2009) and SARAIVA et al. (2011) with pigs $(30-60 \mathrm{~kg}$ ) are taken as reference, requirements of available phosphorus for gain weight are respectively 11.0 and $21.2 \%$ higher than those reported in the present study. These differences between studies may be related to differences between genetic potential, physiological state, age, and growth rate (EKPE et al., 2002). Furthermore, phosphorus requirement can be changed by other factors such as immune system activation. According to KEGLEY et al. (2001), phosphorus requirement for optimal immune response may be greater than that required for maximum growth, since stressing agents can change phosphorus metabolism.

The daily feed intake(DFI), which increased to the level of $0.330 \%$, showed a quadratic effect $(\mathrm{P}<0.05)$ as a function of available phosphorus levels (Table 2), corresponding to the estimated consumption of $5.71 \mathrm{~g} \mathrm{~d}^{-1}$ of available phosphorus according to the equation $\hat{\mathrm{Y}}=-7.8620 \mathrm{x}^{2}+5.1946 \mathrm{x}+0.8763 \quad\left(\mathrm{R}^{2}=0.98\right)$. ALEBRANTE et al. (2011) studied commercial hybrid male and female pigs (15-30kg) and reported a quadratic variation in feed intake as a function of available phosphorus levels $(0.107-0.642 \%)$ in the diet. Similarly, AROUCA et al. (2009) observed a quadratic effect of available phosphorus levels on the feed intake, which increased to $0.430 \%$. SARAIVA et al. (2009) evaluated the available phosphorus levels in feed fed to pigs with high genetic potential (30$60 \mathrm{~kg}$ ) observed no effect on feed intake.

In the present study, it can be observed that levels of available phosphorus lower than $0.330 \%$ affected the voluntary feed intake. According to BÜNZEN et al. (2012), variation in the consumption due to increase in phosphorus levels indicates that pigs are sensitive to inadequate levels of dietary phosphorus since deficiency or excess negatively affects feed consumption. Regarding intake of available phosphorus (aPI), a positive linear effect $(\mathrm{P}<0.01)$ of the treatments was observed on this variable, according to the equation $\hat{\mathrm{Y}}=-0.612522+19.1723 \mathrm{x}\left(\mathrm{R}^{2}=0.98\right)$ (Table 2).

The variation in the available phosphorus levels $(0.100-0.340 \%)$ in the treatments was not sufficient $(\mathrm{P}>0.05)$ to change the hematological parameters (as measured by hemoglobin determination and erythrocyte and leukocyte counts) and differentiate leukocyte cells (neutrophils, basophils, leukocytes, and lymphocytes) (Table 3). The results obtained in the present study are within the range of reference values reported by WEISS \& WARDROP (2010).

According to FRIENDSHIP et al. (1984) the hematological parameters are an important tool to assess animal health. However, they may be influenced by factors as nutritional deficiency, age, and health. Phosphorus is an important element for the phagocytic capacity of polymorphonuclear leukocytes (neutrophils, eosinophils, and basophils) (KIERSZTEJN et al., 1992). Therefore, the correct determination of available phosphorus levels on the basis of hematological parameters is critical for optimal performance of animals. Suboptimal levels may interfere with the production of leukocytes, which are defense cells in the body. ROSTAGNO et al. (2011) recommended the available phosphorus level of $0.322 \%$, which 
Table 3 - Influence of available phosphorus levels in feed for pigs (aged 55-90 days) on blood count, biochemical, and bone variables.

\begin{tabular}{|c|c|c|c|c|c|c|c|c|c|c|}
\hline \multirow{3}{*}{$\begin{array}{l}\text { Complete blood count } \\
\text { Erythrocytes, } \times 10^{6} \mu 1^{-1}\end{array}$} & \multicolumn{8}{|c|}{ 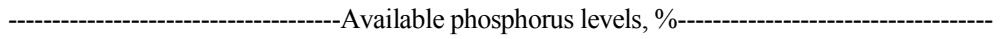 } & \multirow{3}{*}{$\begin{array}{l}\text { P values } \\
0.564\end{array}$} & \multirow{3}{*}{$\begin{array}{l}\mathrm{VC}, \% \\
12.5\end{array}$} \\
\hline & \multicolumn{4}{|c|}{------------0.100----------. --------0.180--------- } & \multicolumn{2}{|c|}{-------0.260------- } & \multicolumn{2}{|c|}{--------0.340------- } & & \\
\hline & 6.1 & \pm 1.2 & 6.2 & \pm 1.4 & 5.8 & \pm 2.1 & 6.5 & \pm 1.1 & & \\
\hline Hemoglobin, $\mathrm{g} \mathrm{dL}^{-1}$ & 12.8 & \pm 2.7 & 13.7 & \pm 2.1 & 12.4 & \pm 1.8 & 14.2 & \pm 1.7 & 0.531 & 15.8 \\
\hline Leucocytes, $\mu 1^{-1}$ & 15,300 & $\pm 1,840$ & 16,250 & $\pm 1,700$ & 14,132 & $\pm 2,199$ & 13,800 & $\pm 1,450$ & 0.250 & 17.8 \\
\hline Neutrophils, \% & 36.3 & \pm 5.2 & 35.4 & \pm 4.5 & 32.9 & \pm 4.8 & 37.0 & \pm 2.5 & 0.325 & 13.5 \\
\hline Lymphocytes , \% & 55.7 & \pm 5.6 & 54.3 & \pm 4.2 & 61.2 & \pm 3.8 & 58.9 & \pm 5.2 & 0.620 & 14.9 \\
\hline Monocytes, $\%$ & 3.7 & \pm 0.80 & 4.0 & \pm 0.67 & 4.2 & \pm 0.54 & 4.1 & \pm 1.1 & 0.350 & 12.2 \\
\hline Basophils, \% & 0.84 & \pm 0.21 & 0.56 & \pm 0.10 & 0.87 & \pm 0.11 & 0.67 & \pm 0.18 & 0.250 & 45.2 \\
\hline Alkaline phosphatase ${ }^{1}, \mathrm{IU} \mathrm{L}^{-1}$ & 197.23 & \pm 106.08 & 149.85 & \pm 32.89 & 133.78 & \pm 35.70 & 120.75 & \pm 36.26 & 0.040 & 40.61 \\
\hline Calcium, $\mathrm{mg} \mathrm{dL}^{-1}$ & 11.16 & \pm 1.10 & 10.85 & \pm 0.69 & 10.3 & \pm 0.83 & 10.12 & \pm 0.27 & 0.274 & 16.59 \\
\hline Phosphorus ${ }^{1}, \mathrm{mg} \mathrm{dL}^{-1}$ & 6.98 & \pm 0.71 & 7.63 & \pm 0.82 & 8.6 & \pm 0.33 & 8.83 & \pm 0.31 & 0.009 & 7.42 \\
\hline Ashes $^{1}, \%$ & 57.71 & \pm 2.43 & 58.69 & \pm 2.99 & 61.32 & \pm 1.02 & 60.44 & \pm 2.38 & 0.033 & 3.90 \\
\hline Phosphorus ${ }^{1}, \%$ & 9.91 & \pm 0.47 & 10.14 & \pm 0.44 & 10.95 & \pm 0.15 & 10.82 & \pm 0.43 & 0.001 & 3.76 \\
\hline
\end{tabular}

${ }^{1}$ Linear effect; NS - Non significant; VC - Variation coefficients.

corresponds to an intake of $6.04 \mathrm{~g} \mathrm{~d}^{-1}$ for pigs (castrated male and female animals; $30-50 \mathrm{~kg}$ ) with high genetic potential. The requirement obtained in the present study for the greatest weight gain, without changes in the hematological parameters, was similar to that recommended by ROSTAGNO et al. (2011).

Decreasing and increasing linear effects $(\mathrm{P}<0.01)$ of the alkaline phosphatase $(\mathrm{AF})$ and $\mathrm{P}$ values were respectively observed as a function of increase in the levels of available phosphorus in the diets, according to the equations $\hat{Y}=217.921$ $306.896 \mathrm{x} \quad\left(\mathrm{R}^{2}=0.90\right)$ and $\hat{\mathrm{Y}}=6.28750+7.70833 \mathrm{x}$ $\left(\mathrm{R}^{2}=0.95\right)$ (Table 3$)$. No effect $(\mathrm{P}>0.05)$ of the aP on serum calcium was observed.

EKPE et al. (2002) assessed phosphorus requirement in growing pigs and reported an inverse relationship between the increase in serum $\mathrm{P}$ concentrations and decrease in enzyme activity. Alkaline phosphatase is involved in enzyme processes of bone formation and maintenance, and phosphorus is the second most abundant mineral in the body. According to AROUCA et al. (2009), the phosphorus serum concentration can be used as an indicator of the condition of this mineral in the body. However, correlating serum phosphorus concentration with the values for optimal performance was not possible in this study, since the serum $\mathrm{P}$ concentration has not reached a plateau.

The available phosphorus levels influenced $(\mathrm{P}<0.01)$ linearly the increase in the bone ash and phosphorus contents in the metacarpal bone of animals, according to the equations $\hat{\mathrm{Y}}=62.2424-1.08232 \mathrm{x}$ $\left(\mathrm{R}^{2}=0.73\right)$ and $\hat{\mathrm{Y}}=10.2291+0.075577 \mathrm{x} \quad\left(\mathrm{R}^{2}=0.81\right)$, respectively (Table 3). Similarly, SARAIVA et al. (2009) studied pigs (30-60kg) and observed a linear increase in the content of bone ash and phosphorus in the bones as a function of available phosphorus in diets. Growing pigs prioritize development of muscles and bones (SHIELDS et al., 1983). However, the requirement for maximum bone mineralization is greater than that for maximum gain weight (KETAREN et al., 1993). Our observations are in agreement with the literature, since the aP levels used in this study were not sufficient to maximize these parameters.

\section{CONCLUSION}

The available phosphorus levels of 0.331 and $0.302 \%$, corresponding to a daily intake of 5.73 and $5.18 \mathrm{~g} \mathrm{~d}^{-1}$, respectively, provide the best results for weight gain and feed conversion in pigs with high genetic potential. The available phosphorus level of $0.340 \%$ in the diet increases serum phosphorus concentration and reduces the alkaline phosphatase activity, but it is not sufficient to meet the requirements for bone deposition.

\section{BIOETHICS AND COMMITTEE APPROVAL}

BIOSSECURITY

This study was submitted to and approved by the Ethics Committee (Center for Animal Technology; Process No. 015_2013).

Ciência Rural, v.46, n.6, jun, 2016. 


\section{ACKNOWLEDGEMENTS}

We thank Fundação de Apoio à Pesquisa e Estudo na Área da Saúde (FAPES) for granting a Master's scholarship to the first author.

\section{REFERENCES}

ALEBRANTE, L. et al. Available phosphorus levels in diets for pigs with high genetic potential for lean meat deposition kept in thermoneutral environment from 15 to 30kg. Revista Brasileira de Zootecnia, v.40, n.2, p.323-330, 2011. Available from: <http://dx.doi.org/10.1590/S151635982011000200013>. Accessed: Aug. 21, 2014. doi: 10.1590/ S1516-35982011000200013.

AROUCA, C.L.C. et al. Exigência de fósforo disponível para suínos machos castrados selecionados para deposição de carne magra, dos 30 aos $60 \mathrm{~kg}$. Arquivo Brasileiro de Medicina Veterinária e Zootecnia, v.61, n.5, p.1094-1103, 2009. Available from: <http:// dx.doi.org/10.1590/S0102-09352009000500012>. Accessed: Aug. 24, 2014. doi: 10.1590/S0102-09352009000500012.

BÜNZEN, S. et al. Níveis de fósforo digestível para suínos em fase de crescimento. Revista Brasileira de Zootecnia, v.41, n.2, p.320-325, 2012. Available from: <http://dx.doi.org/10.1590/ S1516-35982012000200013>. Accessed: Aug. 19, 2014. doi: 10.1590/S1516-35982012000200013.

CORREA, J.A. et al. Effects of slaughter weight on carcass composition and meat quality in pigs of two different growth rates. Meat Science, v.72, n.1, p.91-99, 2006. Available from: <http:// www.sciencedirect.com/science/article/pii/S0309174005002500>. Accessed: Jul. 10, 2014. doi: 10.1016/j.meatsci.2005.06.006.

EKPE, E.D. et al. Digestible phosphorus requirement of grower pigs. Canadian Journal of Animal Science, v.82, n.4 p.541-549, 2002. Available from: <http://pubs.aic.ca/doi/pdf/10.4141/A02006>. Accessed: Aug. 12, 2014. doi: 10.4141/A02-006.

FRIENDSHIP, R.M. et al. Hematology and biochemistry reference values for Ontario swine. Canadian Journal Comparative Medicine, v.48, n.4 p.390-393, 1984. Available from: <http:// www.ncbi.nlm.nih.gov>. Accessed: Jul. 27, 2014.

HITTMEIER, L.J. et al. Genetic background influences metabolic response to dietary phosphorus restriction. Journal of Nutrition Biochemistry, v.17, n.6, p.385-395, 2006. Available from: $<$ http:// www.sciencedirect.com/science/article/pii/S0955286305002172>. Accessed: Jul. 22, 2014. doi: 10.1016/j.jnutbio.2005.08.008.
KEGLEY, E.B. et al. Dietary phosphorus and na inflammatory challenge affect performance and immune function of weanling pigs. Journal of Animal Science, v.79, n.2, p.413-419, 2001. Available from: <http://www.journalofanimalscience.org/ content/79/2/413>. Accessed: Aug. 14, 2014.

KETAREN, P.P. et al. Phosphorus studies in pig. Available phosphorus requirements of grower/finisher pigs. British Journal of Nutrition, v.70, n.1, p.249-268, 1993. Available from: <http:// dx.doi.org/10.1079/BJN19930123>. Accessed: Jun. 13, 2014. doi:10.1079/BJN19930123.

KIERSZTEJN, M.I. et al. On the mechanisms of impaired phagocytosis in phosphate depletion. Journal of the American Society of Nephroly, v.2, n.10, p.1484-1489, 1992. Available from: $<$ http://jasn.asnjournals. org/content/2/10/1484>. Accessed: Aug. 21, 2014.

ROSTAGNO, H.S. et al. Tabelas brasileiras para aves e suínos: composição de alimentos e exigências nutricionais. 3.ed. Viçosa, MG: UFV, Departamento de Zootecnia, 2011. 252p.

SARAIVA, A. et al. Available phosphorus levels in diets for swine from 15 to $30 \mathrm{~kg}$ genetically selected for meat deposition. Revista Brasileira de Zootenia, v.38, n.2, p.307-313, 2009. Available from: <http://dx.doi.org/>. Accessed: Aug. 19, 2014. doi: 10.1590/ S1516-35982009000200013.

SARAIVA, A. et al. Available phosphorus levels in diets for 30 to $60 \mathrm{~kg}$ female pigs selected for meat deposition by maintaining calcium and available phosphorus ratio. Revista Brasileira de Zootecnia, v.40, n.3, p.587-592, 2011. Available from: $<$ http:// dx.doi.org/10.1590/S1516-35982011000300017>. Acesso em: Jun. 04, 2014. doi: 10.1590/S1516-35982011000300017

SHIELDS JUNIOR, R.G. et al. Changes in swine body composition from birth to $145 \mathrm{~kg}$. Journal of Animal Science, v.57, n.1, p.4354, 1983. Available from: <http://www.journalofanimalscience. org/content/57/1/43>. Accessed: Jun. 10, 2014.

SILVA, D.J.; QUEIROZ, A.C. Análise de alimentos (métodos químicos e biológicos). 3.ed. Viçosa, MG: UFV, 2002. 235p.

UNDERWOOD, E.J.; SUTTLE, N.F. The mineral nutrition of livestock. 3.ed. New York: CABI Publishing, 1999. 598p.

UNIVERSIDADE FEDERAL DE VIÇOSA (UFV). Sistemas de análises Estatísticas e Genéticas - SAEG. Viçosa, MG, 2000. (Versão 8.0).

WEISS, D.J.; WARDROP, K.J. Schalm's veterinary hematology. 6.ed. Iowa: Willey Blackwell, 2010. 1232p. 